\title{
AL-MUSAHAMAH AKAD MECHANISM IN JOINT-STOCK COMPANY: A CONTEMPORARY STUDY OF SHARE DIKSI
}

\author{
Basrowi Basrowi*, Pertiwi Utami \\ Universitas Bina Bangsa, Serang, Indonesia
}

Sekolah Tinggi Ekonomi dan Bisnis Islam (STEBI) Lampung, Indonesia

basrowi@binabangsa.ac.id, pertiwiutami@stebilampung.ac.id

https://doi.org/10.46367/iqtishaduna.v10i1.311

Received: Apr 01, 2021 Revised: Apr 29, 2021 Accepted: May 04, 2021 Published: Jun 29, 2021

\begin{abstract}
The musyarakah al-musahamah agreement in Islamic stock transactions is a new thing in the capital market. As a result, investors in the issuer are less knowledgeable about the many forms of sharia products. The purpose of this study is to provide a deeper understanding of step by step and examples of the practice of al-Musahamah akad in the world of stocks. This research uses qualitative methods by becoming literature in contemporary fiqh studies and Islamic economics. The study of contemporary fiqh and Islamic economics is one of the reference materials that can be used to implement the al-musahamah akad in the practice of Islamic finance. The study results found that the study of modern fiqh and fatwas of the Syariah Council and several scholars allow the practice of the al-musahamah akad in the shariah stock business as long as it does not violate the harmony and requirements of sharia. Even though in practice the al-musyarakah akad in joint stock companies in Indonesia is not $100 \%$ by the principles of sharia and modern fiqh, due to the element of use as an objective of sharia and maqasid maslahah, it can be considered to improve existing mechanisms for the better in the future. Supporting previous research that explains the practice of syirkah al-musahamah, this depth research explores the process and practice of the al-musahamah akad in a joint-stock company.
\end{abstract}

Keywords: Al-Musahamah Akad, Joint-Stock Company, Shares.

\section{INTRODUCTION}

In the world of capital markets, various product innovations continue to be developed. Not only the issue of the use of technology and information, to face competition with conventional companies, issuers who have Islamic shares are also required to create products that are able to compete in the business world, especially to attract as many investors as possible. Around 634 issuers competing in the competition for investors will make the competition tighter (Supriyatna 2016).

The facts on the ground are that weak product innovation has an impact on weak market development. Acceleration initiatives can only be carried out if market developments increase and customer/investor interest is getting higher. In addition, many stakeholders, especially investors and issuers, do not understand the concept and implementation of the fatwa of the National Sharia Council. 
Previous studies have stated that the financial literacy of potential investors must be considered, where they must really understand the stages in determining the desired stock investment based on needs. Investing effectively in the stock market is possible only if it is based on scientifically sound methods of analyzing investment instruments (Wielki, Stopochkin, and Sytnik 2019).

Syirkah musahamah is useful in business development because of shares distributed in large numbers. Moreover, syirkah's capital will not change if old shareholders (by selling) exit or enter new shareholders (by using buy). And more interestingly, syirkah musahamah has a special feature and advantages compared to syirkah in general that can create social welfare (not only business people). The reason is that this contract allows the public to become investors in the issuer. As a result, the public can receive a reward in the form of a percentage of the capital provided. Thus, the greater the capital is given, the greater the reward that can be received (Hasanudin and Mubarok 2012). Sharia investment as well as shares is one of the important instruments that has a big part in the process of economic empowerment of a country by creating a division of labor and poverty alleviation (Fathullah 2017). Recent studies reveal that stock investing contributes to people's welfare (Jiang et al. 2020; Wind, Dewilde, and Doling 2020). Investors and investment managers can benefit from investing in stocks. This is done by building an investment portfolio related to asset allocation and responding to existing policies. This also leads to much higher operating profitability and lessens the impact of the financial crisis on issuers (Rahahleh, Akguc, and Abalala 2021). Therefore, the existing investment must have consistency with sharia law so that its benefits can be maximally felt by the community as the goal of sharia and maslahah maqasid (Ghadas et al. 2019).

The study of syirkah al-musahamah in the practice of joint-stock companies needs to be understood more deeply so that in its implementation, it can really be adjusted to the principles of sharia. So far, there have not been many previous studies and studies related to the al-musahamah akad in the practice of joint-stock companies. The implementation procedure is not recorded in the classical fiqh book because it is a new contract. The success of the capital market, publicly listed companies (Tbk), and future shareholders will depend on their ability to innovate, be smart in making decisions, and be competitive in competition and be able to use technology to the full. In addition, this is also needed to avoid public perceptions that capital market products and issuers that have shares labeled as sharia are just copy paste from conventional practices. It is hoped that this mirkamah syirkah study can contribute in reconstructing and reformulating sharia products in order to gain the trust of the public, especially Muslims.

\section{LITERATURE REVIEW}

\section{Basic Mechanisms of Joint-Stock Companies}

In law a joint-stock company is a separate legal entity from shareholders; and has limited responsibilities (Turanl1 2018). Shareholders are only responsible for the company's debt to the value of the money they invest in the company. More in the literature explains that in practice, there needs to be a balance between joint-stock companies and the community, which must be maintained 
properly. One of them is the principle of balance in the offering and the rights of shareholders (buying and selling rights) (Sadeghi, Mousavi, and Estahbanati 2020). Therefore the joint-stock company is also known as a limited company or can be found in the practice of the mutanaqishah musyarakah akad. Whereas a joint-stock company using the al-musahamah akad is not as binding as a limited company, but rather becomes a capital business partner as in the practice of a publicly listed company (Tbk) (Musa 1994).

Syirkah musahamah can be done with the condition that the object does not contain illicit elements such as (alcoholic beverages) and the way to obtain them is not by prohibited business such as stealing or containing ribawi elements, is harmful (there are bad elements), and gambling (Nasution 2006; Humaeroh 2017). As it is known that the issue of shares or new stock exchanges is found in the study of modern jurisprudence in the syirkah section or known as the syirkah al-asham (union in capital) (Dahlan, Abdul A. 1996). Like other syirkah amwal, syirkah musahamah has been in accordance with the rules of syirkah inan figh studies insofar as in practice it does not contain elements of usury and things that are prohibited by sharia (Hasanudin and Mubarok 2012). Syirkah 'inan is characterized by a capital partnership consisting of assets for the results according to the capital invested. In syirkah 'inan, business is very dependent on the members of the syirkah. Not to mention the complicated management when a member of the syirkah leaves (Setiawan 2013). Of course, this incident was not experienced by syirkah al-musahamah because business activities were not affected even though its members changed or stopped (Lita and Utama 2020). Previous studies have explained that the development of the capital market, especially Islamic stocks, continues to increase because there is legal clarity. So that muslim investors began to look at shares with this syirkah (Romansyah 2015).

According to Qardawi (2002), "If the shares traded are from companies engaged in halal business and have consistency with sharia law, then trading halal shares is legal. As explained, shares are certain ownership rights to the assets of a limited liability company or the appointment of these shares. Each share is part of wealth and shares can benefit according to the company's success".

Figure 1 Al-Musahamah Akad Scheme

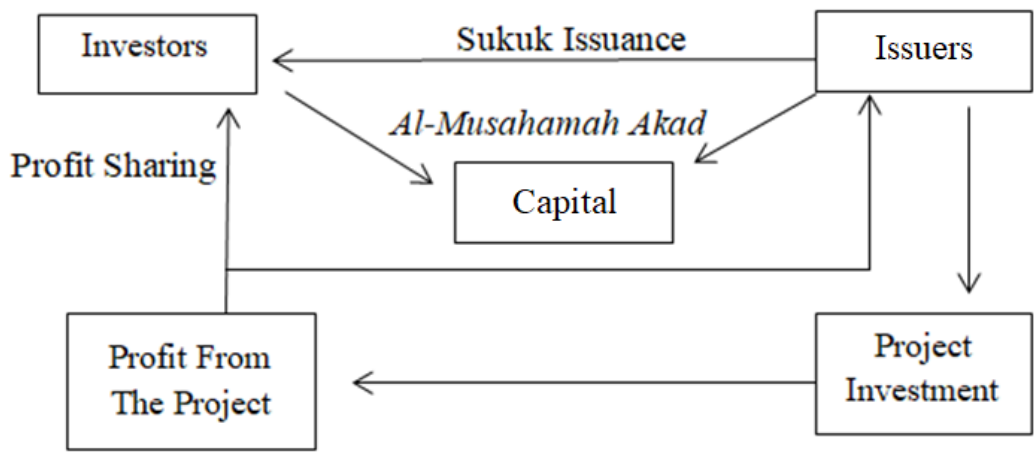

Source: (Hasanudin and Mubarok 2012)

From Figure 1, the mechanism of syirkah musahamah is based on criteria (dhawabith) including; "1) distributed assets in the form of capital valued in cash, 
the transfer of share ownership is carried out with a cash exchange agreement (contract sharf); 2) distributed capital in the form of merchandise or benefits, there is no obstacle to transfer by sale, and profits from merchandise may be received in cash (may not be deferred); 3) capital circulated in the form of merchandise, benefits, money and unified debt, then the legal basis is the law of merchandise and benefits, which can be transferred and sold. While the benefits may be received in cash (may not be suspended (Hasanudin and Mubarok 2012).

\section{Legal Foundation of Contemporary Syirkah}

The syirkah agreement as allowed according to the scholars of fiqh is based on the word of Allah in the an-Nisa (4) verse 12 which reads; "... So they allied in the third one..." (Q.S. An-Nisa': 12). Furthermore, in the prayer letter (34) verse 24 as follows; "... and most of the people who associate with one another they do wrong to another, except those who believe and do righteous deeds ..." (Q.S. Shaad: 24).

The purpose of the two verses above is that this verse refers to the permissibility of the practice of syirkah, of course, as long as it is still within the limits of sharia principles. Lafadz "al-khulatha" can be interpreted as being allied in this context, also called cooperation of two or more parties in conducting business or business (Allamah 2010). Hadith derived from As Said, narrated by Abu Daud; "It was from Saib that he said to the Holy Prophet, "You were once my conglomerate in jahiliyah (times), (at that time) you were my best. You did not set me aside, and did not argue with me" (Shahih: Shahih Ibnu Majah nu: 1853 and Ibnu Majah II: 768 nu: 2287).

The purpose of the above hadith is that if two parties enter into a contract of partnership in various forms, then Allah gives full support to both parties as long as both hold the mandate of their respective rights and obligations. If one of them violates the contract, then Allah will release His pleasure and His blessings from their partnership (Muhammad 1995).

Meanwhile, according to the National Sharia Council of the Indonesian Ulema Council (DSN-MUI) the implementation of syirkah is based on Al-Quran verse Shad letter verse 24. While the pillars and terms of sharia shares are discussed in DSN-MUI Fatwa Nu: 40/DSN-MUI/ X/2003 concerning the Capital Market and General Guidelines for the Application of Sharia Principles in the Capital Market.

In the fatwa collection of DSN-Saudi Arabia chaired by Sheikh Abdul Azi Ibn Abdillah Ibn Baz volume 13 chapter sale and purchase pages 320-321 fatwa number 4016 and 5149 concerning the law of buying and selling of shares is explained that, "If shares traded are not similar to money as a whole such as land, cars, factories, and the like, and this is something that has been known by the seller and buyer, then it is permissible to trade with cash or deferred prices, paid in cash or several times of payment, based on the dhalil's publicity regarding the permissibility of buying and selling that" (Manan 2012).

A different opinion about the practice of syirkah al musahamah was raised by Chapra (1997). According to him, there are a number of factors that can lead to unhealthy practices and speculation on stock prices. Investors use speculation to conduct short-term transactions with forward purchase or sale of margin shares without intending to obtain or take delivery of assets. He buys and sells things that 
he does not consume or use in his business, where he does not work and does not add economic value. In this case, it seems that he does not allow the practice of syirkah al musahamah if it is based on the practice of speculation (Chapra 1997).

Contemporary syirkah is the complexity of syirkah which has been developed by the scholars of four schools and among them syirkah musahamah. Syirkah musahamah is included in amwal syirkah, namely sharing in capital, without looking at the personalities of people or investors who share (Al-Zuhaili 2011). As for the principles such as capital market activities, the activities must refer to the Law and Fatwa of the DSN MUI and as long as they do not conflict with the Capital Market Supervisory Agency (BAPEPAM) and Financial Institution Regulations (Suryomurti 2011).

According to Al-Misri (2007), "Syirkah musahamah is not counted based on the number of legal subjects as in the concept of syirkah in general, but what counts is the amount of equity participation stated in shares because shareholders do not necessarily know each other". Al-Mishri called it a liberal economic instrument. In financial distribution based on shares that are included in the capital and not due to participation in sharia (Al-Misri 2007).

This form of guarantee in contemporary syirkah has similarities with conventional law. First, general guarantees, namely guarantees applied by law for the benefit of creditors in general that all the wealth owned by the debtor is a guarantee of all the agreements and allowances made. Article 1331 of the Civil Code confirms, "All material things, the debtor, both movable and immovable, both existing and new will later become a responsibility for all individual engagement." Second, a special guarantee in the form of the appointment or delivery of certain goods specifically as a responsibility for the repayment of the debtor's obligations to the particular creditor that applies to the creditor. Special collateral consists of an individual guarantee (an underwriter to a creditor to pay off obligations) and a material guarantee (a form of object of economic value). In the above criteria, the law does not specify the types of objects that can be used as collateral, therefore it can be in the form of movable objects, bodily objects or no bodies (Muljadi and Wijdaya 2005).

In the provision of sharia the principle that all one's assets are a guarantee of the agreements made therein are listed in the Sharia Book Civil Code. For example article 307 paragraph 1 of the Kuwait Civil Code and article 391 paragraph 1 of the United Arab Emirates Civil Code, two of the seven shariabased Civil Code. Personal guarantees in sharia law are known as kafalah, the merging of the guarantor's responsibility ( kafil) to guaranteed liability in the face of bills in the form of surrender, debt repayment, or repayment of objects. debt guarantee (Al-Zuhaili 2011). Contemporary Sharia Civil Law distinguishes rahn into a variety of harmony with the doctrine of the development of modern law (Sabiq, t.th). For examples: collateral fidusiad (rahn tasjili), mortgage (rahn ta'mini), and ordinary mortgage (rahn hiyazi). Sharia Standard No. 5 numbers 6.1 to 6.5 stated that other forms of collateral are in the form of bank guarantees, credit documents, use of checks and debt securities, and blocked accounts (Syar'iyyah 2015).

In sharia law, it is explained that the guarantee agreement for an agreement is a guarantee of collateral $\left(t a b^{\prime} i\right)$ which must follow the principal agreement or known as the artificial terms (al-syart al-ja'li), the terms (clauses) made by the 
parties own party. This guarantee conditions, for example, the terms of the contract (al-syart al-muqtarin bi al-qaqd) which are the consequences of the contract, have the purpose of strengthening the contract, and the conditions that have been applied in community practice It should be noted that, this provision in the contract of trust is not permitted, except to guarantee losses in cases of unlawful acts (As-Sanhuri 1956).

There are several types of contracts apart from syirkah musahamah, including equity funds and syirkah inan. Equity mutual funds are based on investing in buying shares where the profits from the ups and downs of stock prices on the stock market (Li et al. 2016; Omri et al. 2019). Meanwhile, syirkah 'inan is a capital-based system with a predetermined profit sharing ratio, which is typically proportional to the capital component. The fundamental difference between the practice of syirkah musahamah and syirkah lies in the members. If the three of them are both a venture capital partnership in the form of stock investment, however, syirkah musahamah are classified as stronger in facing membership changes, because they are open (people can buy their shares) in terms of selling shares in the capital market (Setiawan 2013; Lita and Utama 2020).

\section{METHODS}

This study uses a literature study research design where research used to reveal problems in organizational life and the like can be used as a policy that will be implemented and beneficial to society that is temporary, tentative, and will develop or change after researchers in the field (Sugiyono 2009). Study literature to obtain research results that are in accordance with the background of the problems the researcher found using social research methodology to trace historical data. Based on several articles from previous research, contemporary fiqh studies, and Islamic economics, discussions and results and conclusions will be obtained that are in accordance with the research topic. The data collection is in the form of secondary data obtained from relevant previous studies. Content analysis is used to obtain answers to problems in the study, namely to examine more deeply the practice of the al-musahamah akad in the joint stock company. The content analysis stage begins with the determination of the research design, data retrieval, and search for contextual knowledge. First, formulate research questions, collect data sources, create categories used for analysis, create data collection criteria, and interpret them to obtain conclusions (Hsieh and Shannon 2005).

\section{RESULTS AND DISCUSSION}

\section{Stock Selection Stages}

In general, there are three pillars of syirkah that must be fulfilled. First, the two parties have contracted ('aqidani). The requirement for a person to do the contract is that they must have the ability (Ahliyah) to perform tasharruf (asset management). Second, the object of the contract which is also called ma'qud 'alaihi includes work or capital. The requirements for work, objects, or capital that can be managed in syirkah must be lawful (not haram) and allowed in religion and their management can be represented. Third, the contract or what is also called 
shigat. The legal requirements for the contract in syirkah are that it must be in the form of tasharruf, namely the existence of business management activities that are carried out (Isfandiar 2009; Batubara 2020). After meeting the harmonious criteria and syirkah requirements in general, the stock selection process included in the Jakarta Islamic Index (JII) and the Indonesia Stock Exchange (IDX) as shown in Figure 2.

Criteria for the selection of shares by considering aspects of liquidity and the financial condition of the issuer which consists of five types, namely; 1) choosing a group of shares based on the type of main business that is not contrary to Islamic principles and has been recorded for more than three months (except included in the 10 major capitalists); 2) choose shares based on the annual or midyear financial statements which have a maximum liability to asset ratio of $90 \% ; 3$ ) choose stocks based on the order of the biggest market capitalization during the last year; 4) selecting 30 shares in order based on the average liquidity level of regular trading values over the past year; and 5) conducting a 6-month review by determining the index components at the beginning of January and July each year. In addition, monitoring continuously based on open access data. This syirkah criterion also applies to shares (Isfandiar 2009; Noor, Madnasir, and Hasibuan 2011; Batubara 2020).

\section{Figure 2 Stock Selection Criteria}

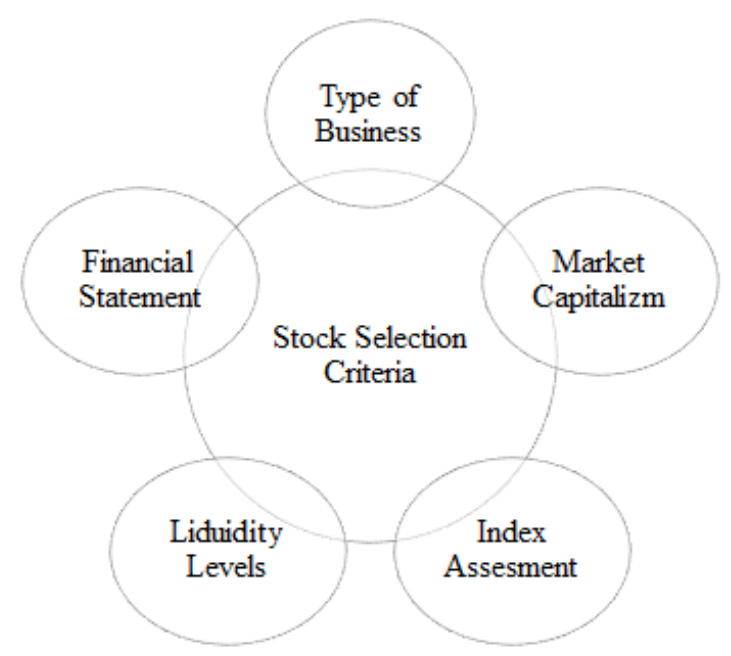

Sources: data processed, (Listyaningsih and Krishnamurti 2015; Husaeni 2018; Rusmita and Swastika 2021)

The method used for the formation of a securities investment portfolio can be based on an analysis of the competitiveness of joint stock companies by identifying the stock market capacity, stock prices, and the company's share in the stock market turnover. Approbation of this developed method makes it possible to identify stocks that are intersecting investments and has the potential to become a scientific basis for effective long-term investments in the stock market (Wielki, Stopochkin, and Sytnik 2019).

Harahap (2014) in his findings also explained several factors that influenced stock prices, including; the results of sales movements, book values, debt ratio movements, and stock price movements. While movements in the value 
of foreign currencies (exchange rates) and interest rates do not affect the price of shares in the Islamic capital market.

Reasons for considering investing in the capital market by buying Islamic stocks in general, among others, because investing in stocks against inflation and stock investments can also prepare the future. By selecting stocks with a strong track record of performance offers the possibility for long-term gains. In addition, it also needs to be seen that the practice of investing in shares that is truly in accordance with the laws and regulations and the DSN-MUI Fatwa.

\section{Musyarakah Al-Musahamah Agreement on the Capital Market}

The contract used in sharia capital stock market practices, such as PT Bursa Efek Tbk, PT XL Axianta Tbk, PT Bumi Teknokultura Tbk, and PT Tembaga Mulia Semanan Tbk, as a whole uses the musyarakah musahamah akad where shareholders can switch easily and quickly and quickly and the nature of the relationship is not bound between two people who are committed. Each shareholder acts as a capital partner and shares the profits and losses, therefore ownership of the shares can be transferred to someone else. There are no specific rules and regulations that apply, especially in the case of sales time, which can be sold at any time because the issuer uses a continuous auction system, not using an acceptable goods system. It's just that this syirkah must meet the harmony as syirkah in general namely; ijab qabul (shighah), there are two parties who make the agreement ('aqidami), there is the object of the contract (ma'qud alayhi) and the profit sharing ratio (Naf'an 2014). While the conditions are; 1) capital must be clear in size and calculation and cannot be separated, it must be one entity; 2) there is a union agreement; 3 ) the condition of the person who has association must be reasonable, mature/baligh, independent and based on their own free will; and 4) rules in the agreement must be clear that there is no element of fraud (Rasjid 2006).

In practice, shares can be sold at any time when stock prices are rising, both on the same day at the same time when making a purchase. Because basically, whenever the shares are sold, the liquidity of the sale of shares will be received on $\mathrm{T}+3$ (the third day after the shares are sold). Islamic stocks do not have a minimum holding period or a maximum limit. These shares can also be inherited according to sharia law. The steps that can be taken if you want to invest in sharia shares while contributing to the development of the nation's economy then can carry out the process as shown in Figure 3.

Figure 3 Process of Opening an Investor Fund Account
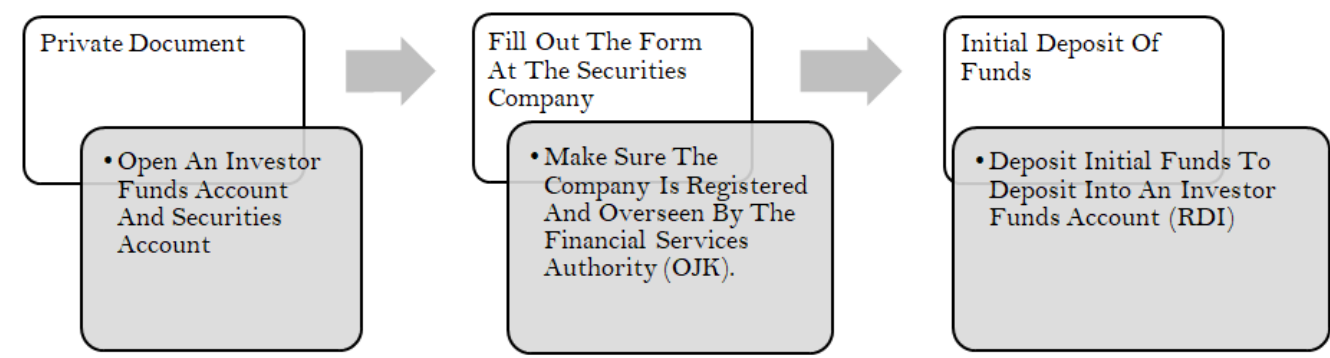

Sources: data processed 
The first step to becoming an investor in the capital market is to open an investor fund account and a securities account. Here, potential investors must prepare a National Identity Card (KTP), Taxpayer Identification Number (NPWP), and savings book. Next, fill in the form at the securities company with a 6,000 stamp to sign the musabakah musahamah akad and several other important documents. And the final step, depositing the initial funds for a deposit. The investor will get two accounts, namely a stock account and an investor fund account.

Investors can choose about 321 registered companies (issuers) that are listed as Sharia Securities List (DES) in the Composite Stock Index (IHSG) constituents. Investors can also use indexes created by the Exchange Authority or other parties such as LQ45, IDX30, and the like as a tool to help select stocks in investing (Supriyatna 2016). When compared with Malaysia, that number is still far behind. In the sharia compliance business, according to the Malaysian Securities Commission report as of May 2015, there were around 674 securities that met sharia requirements which accounted for $75 \%$ of the total 903 securities listed on the Bursa Malaysia. Some of these companies are published by companies that actually run sharia complaints businesses.

After the stages of becoming an Islamic share investor in the capital market has been completed. Next, an example of the flow of practice of the musyarakah musahamah akad can be seen as shown in Figure 4.

Figure 4 Flow of Practices Al-Musahamah Akad at a Joint-Stock Company

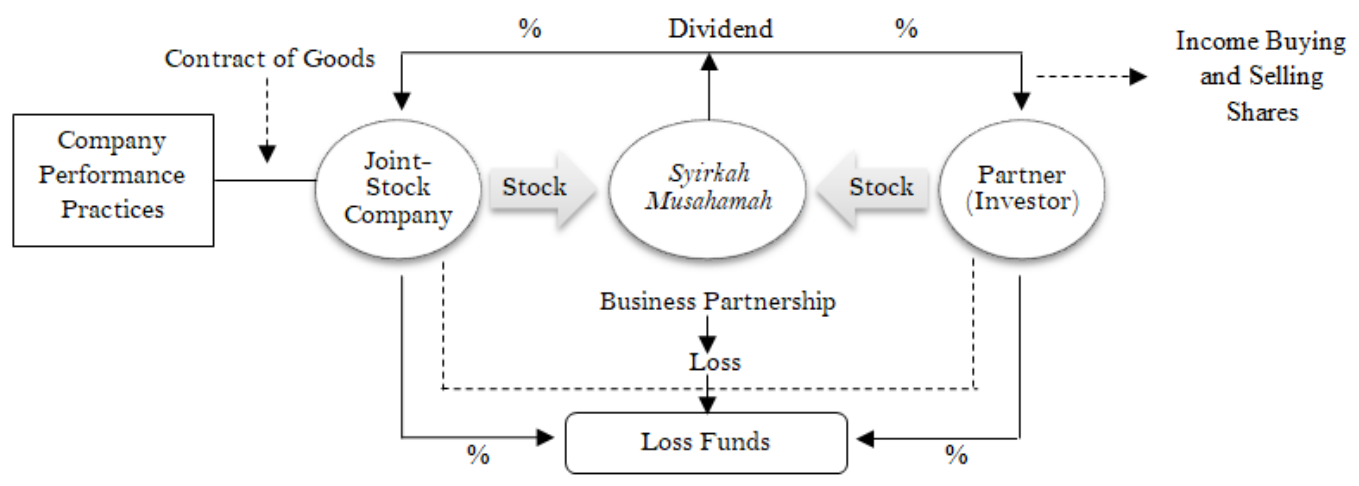

Sources: data processed, (Isfandiar 2009; Hasanudin and Mubarok 2012; Husaeni 2018)

The stages in the musyarakah musahamah akad are; 1) Investors buy Islamic shares, enter into agreements/contracts and select issuers based on existing DES; 2) Joint-stock companies use the musyarakah musahamah akad to do dividends from profits/losses based on a certain percentage according to the condition of the joint-stock company; 3 ) dividends/losses obtained by investors in accordance with the value of shares traded in the capital market (Isfandiar 2009).

For example, researchers took a previous research study on the Indonesia Stock Exchange. There are several types of contracts used in sharia shares: 1) the basic principles of contract agreements include ba' $i$, murabahah, salam, istisna, ijarah and rahn; 2) the contract in the income of buying and selling goods uses mudharabah and musyarakah contracts; 3) the rules in sharia stock contracts are gharar sighat, gharar object, gharar yasir, and commercial risk; and 4) the basic principle of the contract for the goods is that the goods must be clear (muayan) 
and the goods are intact and not divided (musiyak). Based on all that has been explained, the entire contract used in sharia shares in the Indonesia Stock Exchange uses the al-musyarakah musahamah akad. With a short-term share investment time of $<1$ year (less than one year), and long-term $>1$ year (more than one year).

The factors that influence the company's management in making decisions regarding payment of dividends among other things; existing shareholder requirements, access to funds, actual earnings, and maintaining the target debt situation. In other words, dividend policy will affect the value of the company. But dividends are not supported as a tool to reduce information asymmetry and agency costs between management and shareholders. This can be caused by the high ownership structure and one shareholder who can protect the other shareholders well against the application of the interests of the company's management (Sejkora and Duspiva 2015).

The criteria for issuers to enter the DES consist of 2 types, namely; 1) total interest-based debt compared to total assets of not more than 45\%; and 2) total interests income and other non-halal income compared to total revenue and other income not more than $10 \%$.

\section{CONCLUSION}

In practice, the al-musahamah akad in joint-stock companies is not $100 \%$ based on sharia principles because the profits and debts of some issuers still contain non-halal elements. This can be seen from the criteria set by the Capital Market Supervisory Agency of the Financial Services Authority for determining DES. Even so, returning to its useful value, namely the practice of maqasid sharia to build public welfare by increasing the economy through the capital market, certainly deserves to be taken into account. In addition to the issuer's products based on DES itself, they must meet the halal criteria according to the DSN-MUI Fatwa in Indonesia. What is clear, the practice of the al-musahamah akad can encourage economic growth. The research also explains that investors must really consider each Islamic issuer they choose. Because in syirkah, the gains and losses are also divided according to the composition of the capital. In this case, Islamic issuers that use syirkah musahamah are far more profitable because they do not depend on members. After all, shares are openly sold in the capital market.

\section{REFERENCES}

Al-Misri, R. Yunus. 2007. Fiqh Muamalat Al-Maliyah. Damarkus: Dar al-Qalam. Al-Zuhaili, W. 2011. 2011. Al-Fiqh Al-Islam Wa Adillatuh. Edited by Abdul Hayyie. Jakarta: Gema Insani Press.

Allamah, Kamal F.I. 2010. Tafsir Nurul Qur'an Cet. j: Al-Huda.

As-Sanhuri. 1956. Mashadir Al-Haq Fi Al-Fiqh Al-Islami. Kairo: Ma'had alDirasat al- Arabiyyah al- 'Aliyah.

Batubara, Yenni. 2020. "Analisis Maslahah: Pasar Modal Syariah Sebagai Instrumen Investasi Di Indonesia." HUMAN FALAH: Jurnal Ekonomi Dan Bisnis

Islam

2

(7). 
http://jurnal.uinsu.ac.id/index.php/humanfalah/article/view/7246.

Chapra, M. Umer. 1997. Al-Qur'an Menuju Sistem Moneter Yang Adil, Terj.

Lukman Hakim, Dari Towards Al-Qur'an Just Monetary System. Yogyakarta: PT Dana Bhakti Wakaf.

Dahlan, Abdul A., et. al. 1996. Ensiklopedia Islam. Jakarta: PT. Ichtiar Baru Hoeve.

Fathullah. 2017. "Memahami Tinjauan Hukum Islam Dalam Investas." AsySyari'ah: Jurnal Hukum Islam 3 (2): 140-55.

Ghadas, Zuhairah Ariff Abd, Hartinie Abd Aziz, Nurzihan Mohammad Udin, and Mohd Shahril Nizam Md Radzi. 2019. "Social Corporation' The Sharia Business Entity Model: A Corporate Structure with Embodied CSR.” International Journal of Academic Research in Business and Social Sciences 8 (12): 1569-78. https://doi.org/10.6007/ijarbss/v8-i12/5259.

Harahap, Zul Anwar Ajim. 2014. "Konsep Maqasid Al-Syariah Sebagai Dasar Penetapan Dan Penerapannya Dalam Hukum Islam Menurut 'Izzuddin Bin 'Abd Al-Salam (W.660 H)." Tazkir: Jurnal Penelitian Ilmu-Ilmu Sosial $\begin{array}{llll}\text { Dan Keislaman } 9 & \text { (2): 171-90. http://repo.iain- }\end{array}$ padangsidimpuan.ac.id/434/.

Hasanudin, M., and J. Mubarok. 2012. Perkembangan Kesepakatan Musyarakah. Jakarta: Kencana Prenada Media Group.

Hsieh, Hsiu Fang, and Sarah E. Shannon. 2005. "Three Approaches to Qualitative Content Analysis." Qualitative Health Research 15 (9): 1277-88. https://doi.org/10.1177/1049732305276687.

Humaeroh, Humaeroh. 2017. "Eksistensi Syirkah Ta'awuniyah Dalam Perspektif Hukum Islam.” Muamalatuna: Jurnal Hukum Ekonomi Syariah 9 (2): 2033. http://www.jurnal.uinbanten.ac.id/index.php/mua/article/view/2101.

Husaeni, Uus Ahmad. 2018. "Determinants of Capital Structure in Companies Listed in The Jakarta Islamic Index." International Journal of Economics, Management and Accounting 26 (2): 443-56. https://journals.iium.edu.my/enmjournal/index.php/enmj/article/view/504.

Isfandiar, Ali Amin. 2009. "Akad Muamalah Di Pasar Modal Syariah." Jurnal Hukum Islam IAIN Pekalongan 7 (1): 89-105. http://ejournal.iainpekalongan.ac.id/index.php/jhi/article/view/604.

Jiang, Jinglin, Li Liao, Zhengwei Wang, and Hongyu Xiang. 2020. "Financial Literacy and Retail Investors' Financial Welfare: Evidence from Mutual Fund Investment Outcomes in China." Pacific Basin Finance Journal 59: 101242. https://doi.org/10.1016/j.pacfin.2019.101242.

Li, Bob, Mong Shan Ee, Yee Ling Boo, and Mamunur Rashid. 2016. "Islamic or Conventional Mutual Funds: Who Has the Upper Hand? Evidence from Malaysia." Pacific-Basin Finance Journal 42: 183-92. https://doi.org/10.1016/j.pacfin.2016.01.004.

Listyaningsih, Erna, and Chandrasekhar Krishnamurti. 2015. "How Performance of Jakarta Islamic Index (JII) Stocks.” JDM: Jurnal Dinamika Manajemen 6 $145-64$. https://journal.unnes.ac.id/nju/index.php/jdm/article/view/4303.

Lita, Helza Nova, and Zahera Mega Utama. 2020. "Legal Aspect for Managing Waqf Assets Through." Hamdard Islamicus 43 (S-2): 58-63. http://hamdardislamicus.com.pk/index.php/hi/article/view/223. 
Manan, A. 2012. Sharia Economic Law in the Perspective Authority of Religious Courts. Jakarta: Kencana Predatah.

Muhammad, Abu B. 1995. Hadits Tarbiyah Cet. Surabaya: Al-Ikhlas.

Muljadi, K., and G. 2005. Wijdaya. 2005. Privileges, Mortgages and Mortgages. Jakarta: Kencana Prenada.

Musa, K. 1994. Ahkam Al-Muamalat. Beirut: Muassasah ar-Risalah.

Naf'an. 2014. Musyarakah and Mudharabah Financing. Yogyakarta: Graha Ilmu.

Nasution, M.E. 2006. Pengenalan Eksklusif Ekonomi Islam. Jakarta: Prenada Media Group.

Noor, A. Habibi, Madnasir, and Rodo I. P. Hasibuan. 2011. Capital Markets and Sharia Mutual Funds. Bandar Lampung: IAIN Raden Intan Lampung.

Omri, Abdelwahed, Karim Soussou, Nadia Ben, and Sedrine Goucha. 2019. "On the Post-Financial Crisis Performance of Islamic Mutual Funds : The Case of Riyad Funds." Applied Economics 51 (18): 1929-46. https://doi.org/10.1080/00036846.2018.1529403.

Qardawi, Y. 2002. Fatwa Kontemporer. Jilild 3. Jakarta: Gema Insani Press.

Rahahleh, Naseem Al, Serkan Akguc, and Turki Abalala. 2021. "Dow Jones Islamic Index Firms: How Profitable Are They?" International Journal of Islamic and Middle Eastern Finance and Management. https://doi.org/10.1108/IMEFM-09-2019-0379.

Rasjid, S. 2006. Fiqh Islam. Bandung: Sinar Baru.

Romansyah, H. 2015. "Pasar Modal Dalam Perspektif Islam." Mazahib: Jurnal Pemikiran Hukum Islam 14 (1): 1-12. https://journal1.iainsamarinda.ac.id/index.php/mazahib/article/view/332.

Rusmita, Sylva Alif, and Putri Swastika. 2021. "Do Islamic Stock Indexes Integrated with Conventional Stock Indexes ?: Evidence from Indonesia and Malaysia." Asian Management And Business Review (AMBR) 1 (1): 57-67. https://journal.uii.ac.id/AMBR/article/view/17526.

Sadeghi, Mohammad, Sayd Alireza Mousavi, and Alireza Rajabzadeh Estahbanati. 2020. "An Appraisal of Principle of Equilibrium in a Joint Stock Company: From Capabilities to Shortcomings." Private Law 17 (2): 277-99. https://doi.org/10.22059/jolt.2020.304121.1006863.

Sejkora, František, and Pavel Duspiva. 2015. "The Position of Management of Czech Joint-Stock Companies on Dividend Policy." Business Administration and Management XVIII (2): 73-88. https://doi.org/10.15240/tul/001/2015-2-006.

Setiawan, Deny. 2013. "Kerjasama (Syirkah) Dalam Perspektif Ekonomi Islam." $\begin{array}{llll}\text { Jurnal } & \text { Ekonomi } & 21 & \text { (3): }\end{array}$ https://je.ejournal.unri.ac.id/index.php/JE/article/view/1745.

Sugiyono. 2009. Metode Penelitian Dan Bisnis. Bandung: Alfabeta.

Supriyatna, Iwan. 2016. "Ini 26 Emiten Yang Masuk Daftar Efek Syariah 2016." Kompas.Com.

2016. https://money.kompas.com/read/2016/05/25/185650326/ini.26.emiten.yan g.masuk.daftar.efek.syariah.2016?page=all.

Suryomurti, W. 2011. 2011. Super Smart Islamic Investment. Jakarta: Qultum Medai.

Syar'iyyah, Al-Ma'asyir asy. 2015. "Manamah: Accounting and Auditing Organisation for Islamic Financial Institutions." In Standar Syari'ah 
Nomor 5 Angka 6:1-6:5, 134-35.

Turanl1, Hüsnü. 2018. "The Rule of Imperative Provisions for the Joint Stock Companies According to the New Turkish Company Law." International Advisory Board, no. 477.

Wielki, Janusz, Artem Stopochkin, and Inessa Sytnik. 2019. "Investment Portfolio Management Based on the Study of the Competitiveness of Joint-Stock Companies." Quality - Access to Success 20 (July): 387-92.

Wind, Barend, Caroline Dewilde, and John Doling. 2020. "Secondary Property Ownership in Europe: Contributing to Asset-Based Welfare Strategies and the "Really Big Trade-Off." International Journal of Housing Policy 20 (1): 25-52. https://doi.org/10.1080/19491247.2019.1573961. 